\title{
Aerosol seasonal variations over urban-industrial regions in Ukraine according to AERONET and POLDER measurements
}

\author{
G. Milinevsky ${ }^{1}$, V. Danylevsky ${ }^{1}$, V. Bovchaliuk ${ }^{1,2}$, A. Bovchaliuk ${ }^{3}$, Ph. Goloub ${ }^{2}$, O. Dubovik ${ }^{2}$, V. Kabashnikov ${ }^{4}$, \\ A. Chaikovsky ${ }^{4}$, N. Miatselskaya ${ }^{4}$, M. Mishchenko ${ }^{5}$, and M. Sosonkin ${ }^{3}$ \\ ${ }^{1}$ Taras Shevchenko National University of Kyiv, Kyiv, Ukraine \\ ${ }^{2}$ Laboratoire d'Optique Atmosphérique, CNRS - Université de Lille 1, Villeneuve d'Ascq, France \\ ${ }^{3}$ Main Astronomical Observatory, National Academy of Sciences of Ukraine, Kyiv, Ukraine \\ ${ }^{4}$ Institute of Physics, Laboratory of Scattering Media, Minsk, Belarus \\ ${ }^{5}$ NASA Goddard Institute for Space Studies, New York, USA \\ Correspondence to: G. Milinevsky (genmilinevsky@gmail.com)
}

Received: 8 November 2013 - Published in Atmos. Meas. Tech. Discuss.: 13 December 2013

Revised: 5 April 2014 - Accepted: 14 April 2014 - Published: 27 May 2014

\begin{abstract}
The paper presents an investigation of aerosol seasonal variations in several urban-industrial regions in Ukraine. Our analysis of seasonal variations of optical and physical aerosol parameters is based on the sun-photometer 2008-2013 data from two urban ground-based AERONET (AErosol RObotic NETwork) sites in Ukraine (Kyiv, Lugansk) as well as on satellite POLDER instrument data for urban-industrial areas in Ukraine. We also analyzed the data from one AERONET site in Belarus (Minsk) in order to compare with the Ukrainian sites. Aerosol amount and optical depth (AOD) values in the atmosphere columns over the large urbanized areas like Kyiv and Minsk have maximum values in the spring (April-May) and late summer (August), whereas minimum values are observed in late autumn. The results show that fine-mode particles are most frequently detected during the spring and late summer seasons. The analysis of the seasonal AOD variations over the urban-industrial areas in the eastern and central parts of Ukraine according to both ground-based and POLDER data exhibits the similar traits. The seasonal variation similarity in the regions denotes the resemblance in basic aerosol sources that are closely related to properties of aerosol particles. The behavior of basic aerosol parameters in the western part of Ukraine is different from eastern and central regions and shows an earlier appearance of the spring and summer AOD maxima. Spectral single-scattering albedo, complex refractive index and size distribution of aerosol particles in the atmosphere column over Kyiv have different behavior for warm (April-October)
\end{abstract}

and cold seasons. The seasonal features of fine and coarse aerosol particle behavior over the Kyiv site were analyzed. A prevailing influence of the fine-mode particles on the optical properties of the aerosol layer over the region has been established. The back-trajectory and cluster analysis techniques were applied to study the seasonal back trajectories and prevailing directions of the arrived air mass for the Kyiv and Minsk sites.

\section{Introduction}

Aerosol seasonal variations have been investigated in different regions with various ground-based (Gerasopoulos et al., 2007; Jaroslawski and Pietruczuk, 2010; Rana et al., 2009; Andrews et al., 2011; Leskinen et al., 2012; Liu et al., 2012; Pietruczuk and Chaikovsky, 2012), satellite (e.g., Barnaba and Gobbi, 2004; Song et al., 2008), combined groundbased and satellite (e.g., Zawadzka et al., 2013; Bovchaliuk et al., 2013), and balloon-borne (Hara et al., 2011, 2013) techniques for aerosol measurements. The NASA AErosol RObotic NETwork (AERONET; Holben et al., 1998; http: //aeronet.gsfc.nasa.gov/) data are used intensively in such studies. For example, AERONET sun-photometer observations have recently been used (Liu et al., 2012) for study of the seasonal variations in aerosol optical properties in China, including the aerosol optical depth (AOD), Ångström exponent (AE), and single-scattering albedo (SSA). For the 
eastern China region it has been concluded that the AOD is largest in the summer and smallest in the winter, whereas the SSA values exhibit weak seasonal variations with the smallest values during the winter and the largest during the summer. The seasonal behavior of aerosol optical properties determined from vertically resolved in situ measurements over rural Oklahoma, USA, were compared with AERONET data by Andrews et al. (2011). Combined ground-based (AERONET/PHOTONS) and satellite (Moderate-Resolution Imaging Spectrometer, or MODIS) data have been used to study seasonal aerosol content and properties over Europe for 2000-2009 and their impact on ultraviolet (UV) radiance (Chubarova, 2009). The analysis by Jaroslawski and Pietruczuk (2010) of seasonal AOD variations at Belsk (Poland) based on data over the 2002-2007 period reveals two AOD maxima: in April and July-August. In the paper by Zawadzka et al. (2013), the difference in AOD between an urban area (Warsaw) and a rural area (Belsk) during 20052011 was investigated. The estimated influence of urban-area emissions on the AOD was reported as being less than $15 \%$. As reported by Uscka-Kowalkowska (2013), the extinction of direct solar radiation has been studied during the period 1964-2003 in an elevated mountainous region of Poland that can be considered as a non-urban setting. The increased extinction was observed during the spring and summer seasons and showed traits similar to those in urban-industrial areas of eastern Europe. This suggests that the behavior of the aerosol content in this region is governed mainly by the aerosol transport.

In previous analyses (e.g., see Chubarova, 2009; Giles et al., 2012; Pietruczuk and Chaikovsky, 2012; Zawadzka et al., 2013), the eastern European region is considered to be the source of urban-industrial aerosols according to the general aerosol type classification by Dubovik et al. (2002). Indeed, there are many existing and potential aerosol pollution sources in this region, including Ukraine: intensive transport and agriculture, heavy industry, open steppe fields, and mining. Furthermore, this region is characterized by numerous forest, grassland, and peat wildfires, and also can sometimes be considered as a source of biomass burning aerosols (Barnaba et al., 2011; Witte et al., 2011; Bovchaliuk et al., 2013). The steppe regions of southern Ukraine also experience periodical dust storms (e.g., Birmili et al., 2008).

The investigated region is mostly flat terrain with altitude difference between the center and east of Ukraine of about $300 \mathrm{~m}$ above sea level (a.s.l.). The developed heavy industry is concentrated in the Donetsk, Lugansk, and Kharkiv metropolitan areas; industry and open mines are typical of east-central Ukraine (Dnipropetrovsk and Kirovograd areas); while steppes are located in the south and the southeast of Ukraine (Fig. 1).

In the west of Ukraine the altitude increases to about $400 \mathrm{~m}$ a.s.l. with mountains up to $2000 \mathrm{~m}$ high in the far southwest. This part of Ukraine is less populated and has lower industrial load (the Rivne and Lviv city areas).

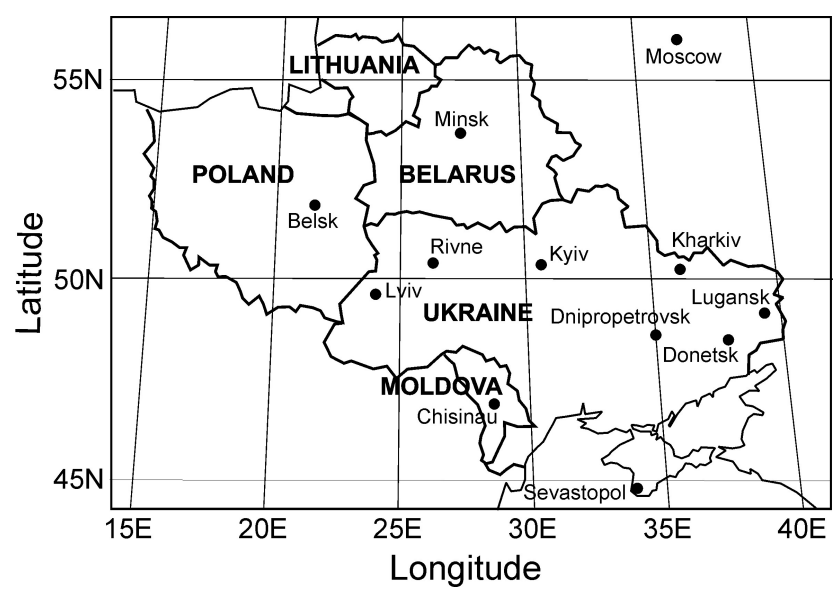

Figure 1. Locations of the AERONET sites (Kyiv, Lugansk, Sevastopol, and Minsk) and areas covered by POLDER measurements (Kyiv, Lugansk, Donetsk, Kharkiv, Dnipropetrovsk, Lviv, Rivne, and Minsk) as discussed in this paper.

Therefore, the potential urban-industrial aerosol sources are concentrated in the east, east-central and southeast regions. For big cities like Kyiv and Kharkov, a large potential source of aerosols is car traffic. For example, the concentration of cars in the central part of Kyiv sometimes reaches 800 vehicles per kilometer, producing $\sim 90 \%$ of all atmospheric pollution in the area.

Previous studies (e.g., Chubarova, 2009; Bovchaliuk et al., 2013; Ogunjobi et al., 2008; Israelevich et al., 2012) show that the aerosol seasonal behavior in the eastern European region strongly depends on regional/latitudinal conditions. The seasonal variability of aerosols in the atmosphere over Ukraine has been less studied due to the lack of data collection from ground-based observations in previous years. A preliminary analysis of general aerosol parameters for the eastern European region has been done by the authors (Bovchaliuk et al., 2013). In continuation of our previous study, we focus here on an analysis of seasonal aerosol properties and dynamics over the urban-industrial areas of Ukraine based on AERONET sites and POLDER/PARASOL satellite imaging spectroradiometer data. Unlike the preceding paper (Bovchaliuk et al., 2013) we analyze the variation of the total AOD, the fine- and coarse-mode components of the AOD and volume concentration, the spectral SSA, and the refractive index (RI) for AERONET sites in Ukraine and expand the analysis of the POLDER data to a larger number of urban areas. The purpose of the analysis is to determine dominant aerosol types in individual seasons. In Sect. 2, we describe the instrumentation and measurement sites/regions. Seasonal variations of aerosol parameters are analyzed in Sect. 3. We discuss and compare the results for individual sites and regions in Sect. 4 and make concluding remarks in Sect. 5. 


\section{Description of instrumentation and measurement sites}

\subsection{AERONET data and sites}

A convenient and powerful method for studying the aerosol content and parameters is ground-based measurements with the AERONET/PHOTONS sun-photometer network (Holben et al., 1998), which allows obtaining long-term series of uniform and accurate data for the analysis of variations on different timescales. The sun-photometer data are also useful in satellite retrieval validation (e.g., see King et al., 1999; Fan et al., 2008; Li et al., 2009; Mishchenko et al., 2010; Schuster et al., 2012). Studies of aerosol content and property data collected by satellite measurements over specific regions with AERONET sites and joint satellite and ground-based data analyses allow one to determine aerosol seasonal dynamics and deduce the aerosol behavior pattern. We use this approach in our investigations for the Ukrainian territory. The AERONET network has been recently expanded in the central part of eastern Europe (Danylevsky et al., 2011; Milinevsky et al., 2012; Milinevsky, 2013). At present, the two AERONET sites are continuously operated there: the Kyiv site (operated since 2008) in Ukraine and the Minsk site (operated since 2002) in Belarus. The data from the Sevastopol site (operated since 2006) in Ukraine have been described in detail by Bovchaliuk et al. (2013) and are partly used in our analysis in Sect. 4. Also data from the Lugansk site, which has been operated periodically since 2011, are included in our consideration in comparison to POLDER data. The data from these three AERONET sites in Ukraine and one site in Belarus for comparison purposes have been used for analysis of aerosol seasonal features in this paper together with POLDER data for several urban-industrial regions in Ukraine. The information on AERONET sites and the Ukrainian urban-industrial areas selected for our analysis using POLDER data is given in Table 1. The Kyiv AERONET site has the longest data record in the region. Therefore, to evaluate seasonal aerosol variations we perform the most detailed analysis for that area.

For the purposes of this paper, mostly level 2.0 cloudscreened and quality-assured data were used. In a few cases, when level 2.0 data were not available, we used level 1.5 (cloud-screened and outliers removed) data. In such cases the sign "level 1.5" appears in relevant figure. The AERONET Version 2 direct sun and inversion algorithms and software were used for the determination of aerosol properties from sun-photometer measurements (Dubovik and King, 2000; Dubovik et al., 2000, 2006; http://aeronet.gsfc.nasa.gov/).

For aerosol dynamics analysis in this paper, we extracted the aerosol Version 2 direct sun algorithm (DSA) level 2.0 parameters from the AERONET database: daily and monthly weighted averages of AOD at 440 and $870 \mathrm{~nm}$, and the Ångström exponent values computed using the 440$675 \mathrm{~nm}$ and $440-870 \mathrm{~nm}$ channels. The almucantar retrievals
Inversion Products level 2.0 and level 1.5 were obtained from the AERONET database: level 2.0 size distribution and volume concentration, level 1.5 SSA and complex RI, level 1.5 absorption AOD and extinction AOD. To determine the seasonal behavior, we calculated monthly averaged parameters during the period 2008-2013 for the Kyiv site, 2002-2013 for the Minsk site, and November 2011-August 2013 for the Lugansk site. The Ångström exponent $(675-870 \mathrm{~nm})$ was calculated from level 2.0 AOD data.

The AOD value is a general measure of the total aerosol amount in the atmospheric column. The AE is a parameter related to the aerosol particle size distribution and depends on the effective radius of particles that allows dividing aerosol by fraction: a small AE pertains to coarse-mode particles, while a large AE corresponds to small (fine-mode) particles. But it is influenced also by effective variance of the size distribution (Tanré et al., 2001; Schuster et al., 2006; Kokhanovsky, 2008). For the AE value analysis, we calculated the AE according to the AERONET procedures as $\alpha\left(\lambda_{1}, \lambda_{2}\right)=\ln \left[\operatorname{AOD}\left(\lambda_{1}\right) / \operatorname{AOD}\left(\lambda_{2}\right)\right] / \ln \left(\lambda_{2} / \lambda_{1}\right)$ using $\mathrm{AOD}$ data (Holben et al., 1998).

We use also the volume concentration AERONET parameter, which is the total volume of aerosol particles per unit surface area (in $\mu \mathrm{m}^{3} \mu \mathrm{m}^{-2}$ ), to infer its seasonal variation. The volume concentration value is calculated from sun-photometer measurements of the spectral sky radiance distribution along the solar almucantar using the inversion algorithm and software by Dubovik and King (2000). The standard AERONET inversion algorithm provides these data under the assumption of a bimodal log-normal particle size distribution using sky radiance measurements along the solar almucantar for solar zenith angles (SZA) ranging from 75 to $50^{\circ}$.

The accuracy of retrieving aerosol particle properties is an important aspect of solving inverse problems. The spectral AOD values from the AERONET Version 2 DSA are retrieved with errors \pm 0.01 in the visible and near-infrared parts of the spectrum and with a larger uncertainty $( \pm 0.02)$ in the UV band (Holben et al., 1998). The AE uncertainty is on the order of $\sim 0.1$. The retrieval accuracy for the particle volume size distribution $\mathrm{d} V(r) / \mathrm{d} \ln r$, complex RI, and SSA depends on many factors, e.g., the sun-photometer calibration, AOD, solar zenith angle range, and particle sizes (Dubovik et al., 2000). The accuracy of the particle volume size distribution $\mathrm{d} V(r) / \mathrm{d} \ln r$ is adequate essentially in the entire range of AODs (e.g., AOD $(440 \mathrm{~nm}) \geq 0.05)$. In particular, for the intermediate particle size range $(0.1 \leq r \leq 7 \mu \mathrm{m})$, the retrieval errors do not exceed $10 \%$ in the maxima of the size distribution and may increase up to about $35 \%$ for the size bins corresponding to the minimum values of $\mathrm{d} V(r) / \mathrm{d} \ln r$ in this size range. The $\mathrm{d} V(r) / \mathrm{d} \ln r$ retrieval errors rise to $80-100 \%$ (and even higher) for sizes smaller than $0.1 \mu \mathrm{m}$ and larger than $7 \mu \mathrm{m}$ (Dubovik et al., 2000).

The SSA values with an accuracy of $\sim 0.03$ and complex RI values with errors of $\sim 30-50 \%$ for the imaginary part and 
Table 1. AERONET sites and Ukrainian urban-industrial areas selected for analysis.

\begin{tabular}{lll}
\hline Site/area & Coordinates, elevation a.s.l. & Instrumentation \\
\hline Kyiv, Ukraine & $50.36^{\circ} \mathrm{N}, 30.50^{\circ} \mathrm{E}, 200 \mathrm{~m}$ & AERONET/POLDER \\
Lugansk, Ukraine & $48.57^{\circ} \mathrm{N}, 39.36^{\circ} \mathrm{E}, 90 \mathrm{~m}$ & AERONET/POLDER \\
Donetsk, Ukraine & $48.03^{\circ} \mathrm{N}, 37.81^{\circ} \mathrm{E}, 300 \mathrm{~m}$ & POLDER-AERONET \\
Kharkiv, Ukraine & $50.00^{\circ} \mathrm{N}, 36.23^{\circ} \mathrm{E}, 135 \mathrm{~m}$ & POLDER \\
Dnipropetrovsk, Ukraine & $48.45^{\circ} \mathrm{N}, 34.98^{\circ} \mathrm{E}, 68 \mathrm{~m}$ & POLDER \\
Rivne, Ukraine & $50.62^{\circ} \mathrm{N}, 26.25^{\circ} \mathrm{E}, 230 \mathrm{~m}$ & POLDER \\
Lviv, Ukraine & $49.83^{\circ} \mathrm{N}, 24.00^{\circ} \mathrm{E}, 270 \mathrm{~m}$ & POLDER \\
Sevastopol, Ukraine & $44.62^{\circ} \mathrm{N}, 33.52^{\circ} \mathrm{E}, 80 \mathrm{~m}$ & AERONET/POLDER \\
Minsk, Belarus & $53.92^{\circ} \mathrm{N}, 27.60^{\circ} \mathrm{E}, 200 \mathrm{~m}$ & AERONET/POLDER \\
\hline
\end{tabular}

$\sim 0.04$ for the real part can be retrieved only for high aerosol loading, with AOD $(440 \mathrm{~nm}) \geq 0.5$. For observations with lower aerosol loadings, the retrieval accuracy of SSA and RI estimations significantly worsens. Dubovik et al. (2000) have shown that the accuracy levels worsen to $0.05-0.07$ for SSA, $80-100 \%$ for the imaginary part of the RI, and 0.05 for the real part of the RI when AOD $(440 \mathrm{~nm}) \leq 0.2$. Though the uncertainties in the aerosol characteristics over observational sites can be significant, we assume that monthly averaged aerosol parameters over the whole period of observation allow us to describe the seasonal behavior of aerosol properties in the represented regions of Ukraine.

\subsection{POLDER/PARASOL data and regions}

Satellite instruments can provide the aerosol distribution data in the atmosphere over eastern Europe. The data acquired by the POLDER-3 imager on the PARASOL satellite (http://www.icare.univ-lille1.fr/parasol/; operated from December 2004 to October 2013) have been used to investigate aerosol seasonal variations over the listed specific regions of Ukraine (Fig. 1 and Table 1). The aerosol parameters derived from the POLDER measurements are the AOD in the $865 \mathrm{~nm}$ band and the AE determined using the AODs in the 865 and $670 \mathrm{~nm}$ bands. The instrument allows obtaining the aerosol amount and the parameters of fine-mode particles with sizes less than $0.3 \mu \mathrm{m}$ from measurements of polarized back-scattered solar radiation (Deuzé et al., 2001; Fan et al., 2008; Tanré et al., 2011). The fine-mode aerosols are produced mainly by anthropogenic sources and by biomass burning events, anthropogenic or natural (Tanré et al., 2001; Dubovik et al., 2002; Anderson et al., 2005; Kaufman et al., 2005; Amiridis et al., 2010; Chubarova et al., 2012). The polarized light measurements serve for improvement of the retrieval accuracy over land surfaces (Deuzé et al., 2001; Kokhanovsky et al., 2007; Mishchenko et al., 2007; Cairns et al., 2009), and this was the main reason for using POLDER instrument data for the analysis of the atmospheric contamination over Ukraine by anthropogenic aerosols. The POLDER instrument and data-processing algorithms are described by Deschamps et al. (1994), Bréon (2006), and
Kokhanovsky et al. (2007) (http://www.icare.univ-lille1.fr/ parasol/). The standard algorithm is based on the approach wherein the polarized light scattered by the aerosols is analyzed by assuming monomodal models of spherical nonabsorbing particles and uses the look-up table method by Deuzé et al. (2001). The retrieval accuracy has been investigated for aerosol parameters over ocean (Herman et al., 2005; Goloub et al., 1999) and land. The correlation with AERONET sun-photometer data is 0.77-0.95 depending on the location of ground-based sites (Bréon et al., 2011; Fan et al., 2008; Bovchaliuk et al., 2013). The standard cloud-screening algorithm has been used for the processing of POLDER measurements over land surfaces (Bréon and Colzy, 1999). In our investigation we use only cloud-free pixels. More details on analysis methodologies using POLDER data can be found in our previous paper (Bovchaliuk et al., 2013).

The monthly mean AOD values at $865 \mathrm{~nm}$ and AE values at $670-865 \mathrm{~nm}$ for the period from 2008 to 2011 over the Ukrainian urban-industrial areas around the cities of Kyiv, Lugansk, Donetsk, Kharkiv, Dnipropetrovsk, Lviv, and Rivne and the Belarus city of Minsk were derived from POLDER data using the algorithm described in Deuzé et al. (2001). For the analysis, we used POLDER data for $18 \mathrm{~km} \times 18 \mathrm{~km}$ grid cells (Deuzé et al., 2001; Bovchaliuk et al., 2013) on the Earth surface centered on cities mentioned above.

It should be emphasized that satellite measurements are affected by the snow cover and significant cloudiness in the winter. Moreover, fewer data are available in the winter for latitudes above $50^{\circ} \mathrm{N}$, because the solar elevation is too low to allow the AOD retrieval. This is the reason why the sparse data for January were not analyzed. The underlying surface in this region varies in the spring and autumn due to the variable vegetation cover. In addition, the surface effect on polarization is relatively greater when the amount of aerosols in the atmosphere is small. However, for purposes of the POLDER and AERONET data comparison, it was considered that the environmental conditions at the Kyiv and Minsk AERONET sites are very similar. The sites are located nearby or within big cities surrounded by forests 
and agricultural lands with similar, relatively flat landscapes. This allows us to assume that the reflectance properties of the land surfaces around these sites for POLDER retrievals are similar during a year. The comparison of the POLDER AOD $(865 \mathrm{~nm})$ and the AERONET AOD $(870 \mathrm{~nm})$ for fine-mode particles $(r<0.3 \mu \mathrm{m})$ measured at the Moscow, Minsk, Belsk, Kyiv, Moldova, and Sevastopol AERONET sites shows good agreement of the respective data. In general, the correlation coefficients for AOD $(865 \mathrm{~nm})-$ AOD $(870 \mathrm{~nm})$ are in the range $0.76-0.93$ except the value for the Sevastopol site (0.63), while the standard deviations in the POLDERAERONET comparisons are less than 0.02 for the range of AOD values between 0.01 and 0.25 . A detailed comparison of AERONET sun-photometer data and POLDER instrument data is given for all eastern European AERONET sites in Bovchaliuk et al. (2013).

\section{Results}

\subsection{Seasonal variability of AOD and volume concentration}

For analysis of aerosol dynamics and optical properties in the atmosphere over eastern European region, the AOD (440 nm) AERONET sun-photometer data are most appropriate because of the highest statistical accuracy of the measurements as compared with other spectral channels of the sun photometer. In general, the data of the $440 \mathrm{~nm}$ spectral channel were often used for aerosol content and optical property studies in different regions of the planet (e.g., Dubovik et al., 2002; Boselli et al., 2012). Furthermore, the AOD (440 nm) is used as reference data in the AERONET algorithm in the accuracy estimations of the aerosol particle optical and microphysical properties (Dubovik and King, 2000; Dubovik et al., 2000, 2006).

However, it should be mentioned that the $440 \mathrm{~nm}$ spectral channel corresponds to the $\mathrm{NO}_{2}$ molecular absorption band (Burrows et al., 1998). The $\mathrm{NO}_{2}$ impact is considered in the AERONET algorithms using the satellite data from OMI, SCIAMACHY, and GOME instruments (see AERONET Version 2 DSA, http://aeronet.gsfc.nasa.gov/). But the satellite $\mathrm{NO}_{2}$ data uncertainties are still rather large (Boersma et al., 2004, 2011). Since the $\mathrm{NO}_{2}$ concentration in the troposphere is determined mainly by anthropogenic sources like fossil fuel combustion (Enhalt et al., 2001), in a case of urban-industrial regions we therefore cannot exclude probable influence of $\mathrm{NO}_{2}$ on measured AOD $(440 \mathrm{~nm})$ values. To estimate this influence we can use the optical remote sensing data received for urban regions in USA (Alexandrov et al., 2002a, b). Though the yearly mean values of the $\mathrm{NO}_{2}$ atmospheric extinction, e.g., over New York city (measurements at $440 \mathrm{~nm}$ from September 1995 till November 1996) were below 5 Dobson units (DU), on some days the extinction value reached $15 \mathrm{DU}$. Considering the absorption cross sections of $\mathrm{NO}_{2}$ given in Burrows et al. (1998), the corresponding extinction optical thickness is 0.07 for the $5 \mathrm{DU}$ and 0.2 for the $15 \mathrm{DU}$ case. This value exceeds significantly the errors of AOD measurements by AERONET sun photometers in the $440 \mathrm{~nm}$ spectral band (Holben et al., 1998).

According Rublev et al. (2004) the $\mathrm{NO}_{2}$ concentration at $0.5 \mathrm{~km}$ altitude in Moscow at rush hour times corresponds to extinction of about 13.7 DU and that is approximately equal to the AOD $(440 \mathrm{~nm})$ value of about 0.18 . The measurements over the Kyiv and Minsk sites show that mean values of the AOD $(440 \mathrm{~nm})$ are 0.25 and 0.23 , respectively (see Table S1 in the Supplement), and in most of cases (with few exceptions of forest wildfire event and dust storm; Bovchaliuk et al., 2013) they are less than 0.5 , which is a crucial value for the AERONET inversion algorithm to the SSA and RI aerosol particle determination. Though Kyiv and Minsk are not such big cities compared to New York and Moscow, $\mathrm{NO}_{2}$ could impact AERONET AOD $(440 \mathrm{~nm})$ data in urbanindustrial regions like those considered in our paper. Among the spectral channels of AERONET sun-photometer CE3182 the channel $870 \mathrm{~nm}$ is free from $\mathrm{NO}_{2}$ influence. Moreover this spectral band corresponds to the main spectral channel of the POLDER instrument. However, in Kyiv and Minsk the AOD $(870 \mathrm{~nm})$ are 2-3 times lower than the AOD $(440 \mathrm{~nm})$, and consequently the relative errors of the AOD $(870 \mathrm{~nm})$ measurements are proportionally larger than for the AOD $(440 \mathrm{~nm})$. Therefore, it looks reasonable to use the data from both spectral channels for evaluation of seasonal variations of aerosol optical properties in this paper.

The monthly mean AOD (440 and $870 \mathrm{~nm}$ ) values and AE $(440-870 \mathrm{~nm})$ data retrieved by the AERONET DSA have been averaged over the 2008-2013 period (the Kyiv site) and over the 2002-2013 period (Minsk site) to reveal the aerosol content and optical properties seasonal peculiarities. According to our results, the AOD values exhibit two maxima: in spring (April-May) and in the second half of summer (August). Note that the summer AOD maximum is larger and is seen in both spectral channels, but spring maximum is clearly seen in $440 \mathrm{~nm}$ only and occurs mostly in April (the Kyiv site) and in April-May (the Minsk site) (Fig. 2a-c).

The aerosol spectral characteristics in $440-870 \mathrm{~nm}$ channels are changed significantly during two spring months (March-April) over the Kyiv site, which is confirmed by the Ångström exponent variation from 1.35 to 1.50 (see in Fig. 2d). These spring changes are not so prominent over the Minsk site. In contrast the aerosol particle spectral characteristics' variation during summer months (July-August over Minsk and June-August over Kyiv) is even stronger: the Ångström exponent mean value difference equals about 0.25 (over Minsk) and 0.17 (over Kyiv), which is evidence of a less homogeneous composition of aerosol particles in the summer than in the spring. The POLDER AOD $(865 \mathrm{~nm})$ values for the Kyiv and Minsk areas are shown in Fig. 2a and c by open diamonds, and they are lower than the AERONET data, having traits in general similar to the AOD $(870 \mathrm{~nm})$ 


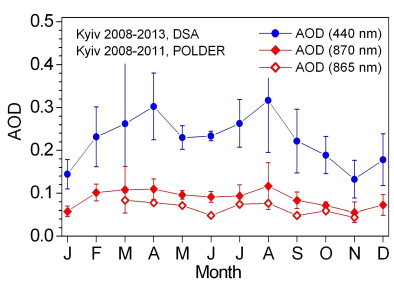

(a)

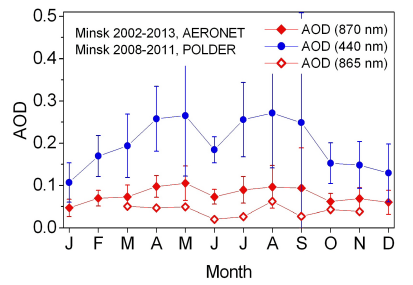

(c)

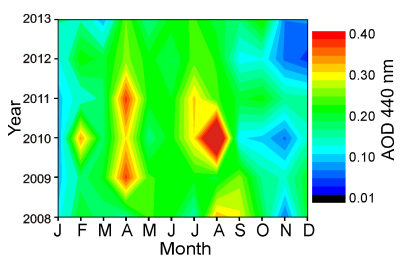

(e)

Figure 2. (a-c) The AOD $(440 \mathrm{~nm})$ and the AOD $(870 \mathrm{~nm})$ mean value seasonal changes by AERONET data and the AOD $(865 \mathrm{~nm})$ by POLDER data for the Kyiv and Minsk sites, (d) the set of Ångström exponent (440-870 nm) values, (e) the features of AOD (440 nm), and (f) Ångström exponent (440-870 nm) season variations at the Kyiv site from year to year. Vertical bars show monthly mean standard deviations from averaged values. Months are shown by their first letters in the order January-December.

values. The AOD $(865 \mathrm{~nm})$ is lower than the AOD $(870 \mathrm{~nm})$ because POLDER data are determined by fine-mode particles in contrast to AERONET total (fine and coarse modes) particle AOD. Results in Fig. 2a-c show the season behavior of AOD and Ångström exponent parameters on average having the strong variation from year to year (see Fig. 2e and $\mathrm{f})$. In the case of the Kyiv site, AOD $(440 \mathrm{~nm})$ and Ångström exponent seasonal variability are influenced by several strong events, which are not always similar in the AOD and the AE. For example, the strong AOD $(440 \mathrm{~nm})$ event in April 2009 corresponds to the high AE values, but a similar AOD (440 nm) event in April 2011 and the strong AOD (440 nm) event in August 2010 correspond to the mean $\mathrm{AE}$ values.

The monthly mean total, fine-mode and coarse-mode volume concentration values retrieved from the AERONET database and averaged over 2008-2013 have been used for estimation of aerosol particle content seasonal changes (Fig. 3). We could expect strong correlation between the total volume concentration and the AOD values. However,

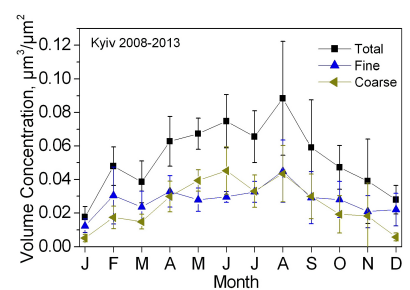

(a)

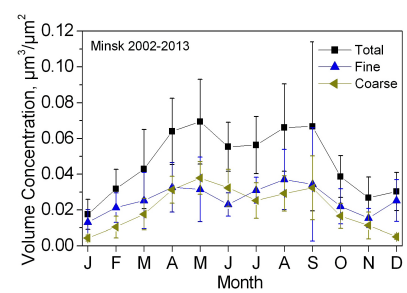

(b)
Figure 3. Seasonal behavior of aerosol volume concentration of total, fine- and coarse-mode particles over the (a) Kyiv and (b) Minsk AERONET sites.

the correspondence of these values exists only in general in the case of the Kyiv site. The AOD and the total volume concentration over the July-November period reaches maximum in August and decreases monotonously in SeptemberNovember. The total volume concentration over the Kyiv area has its minimum in winter months when fine-mode particles prevail and increases during spring (from March to June) mainly due to increase of the coarse-mode particle concentration. During May and June the coarse-mode particles prevail over the Kyiv site, but the AOD variation in both these months and in the rest of the year corresponds mainly to the fine-mode particle volume concentration. The AOD (440 nm) and AE (440-870 nm) have the sharp maxima in April and August, whereas volume concentrations of the fine- and coarse-mode particles are practically the same at this time, which can be interpreted as a prevailing influence of the fine-mode particles on the optical properties of the aerosol layer over the Kyiv site.

The AOD and the total volume concentration of the particles over the Minsk site better fit one another (Figs. 2c and $3 \mathrm{~b}$ ), as well as in the case of fine- and coarse-mode variations. The relevant data have the same trend during all months except July and December. Total volume concentration has two maxima in April-May and August and has the minimum in winter months like in the Kyiv site.

The difference in the AOD and the total volume concentration variations over the Kyiv site can partially be explained by conditions of the measurement selection, because the AOD is determined from direct sun observations that are performed every $15 \mathrm{~min}$ at SZA $28-82^{\circ}$ during summer (SZA $>73^{\circ}$ in winter) at the Kyiv site, but sky almucantar measurements are carried out for limited SZA values (Holben et al., 1998). Therefore, the volume concentration and physical properties of aerosol particles are determined in different conditions and using a smaller number of measurements. We have created the shortened series of the monthly mean $\mathrm{AOD}$ and $\mathrm{AE}$ measurements that consists of direct sun observations coincident with sky almucantar measurements to reveal the observation condition difference impact on seasonal variations (Fig. $2 \mathrm{~d}$ and f). We reveal that observational selection, i.e., amount and condition of observations, 
influences the AOD data to a different extent for different months. The influence is largest in the winter and in the early spring. Also it is noticeable during the second half of the summer and in the late fall. For example, in January the averaged AOD $(440 \mathrm{~nm})$ value determined from the direct sun irradiance measurement is $\sim 30 \%$ larger than the $\mathrm{AOD}_{\mathrm{Alm}}$ $(440 \mathrm{~nm})$ value determined from direct sun irradiance measurements coincident with the sun almucantar scanning of the sky. Also, in March the AOD $(440 \mathrm{~nm})$ is $\sim 26.5 \%$ larger than $\mathrm{AOD}_{\mathrm{Alm}}(440 \mathrm{~nm})$. In summer and in two autumn months the AOD $(440 \mathrm{~nm})-\mathrm{AOD}_{\mathrm{Alm}}(440 \mathrm{~nm})$ difference is less than $\sim 10 \%$, increasing to $\sim 16 \%$ in November and December. The AOD $(440 \mathrm{~nm})-\mathrm{AOD}_{\mathrm{Alm}}(440 \mathrm{~nm})$ relationships vary in the same way as AOD values increasing in the spring with maximum in April, and increasing in the late summer with maximum in August. These regularities appear at both the 440 and $870 \mathrm{~nm}$ spectral channels. The AE ( $440-870 \mathrm{~nm})$ values have a reduced amount and correspond to bad observation conditions mainly during winter. For the remainder of the year the AE values of both sets vary in a similar manner but with higher values of almucantar coincident AE; see Fig. 2d.

Using POLDER data we investigated seasonal variation of the AOD (865 nm) and Ångström exponent (670-865 nm) values over the Ukrainian urban-industrial areas centered on the cities Kyiv, Lugansk, Donetsk, Kharkiv, Dnipropetrovsk, Lviv, and Rivne and on the Belarus city Minsk (Fig. 4).

Similar to the central part of Ukraine (the Kyiv site) and Belarus (the Minsk site) the seasonal AOD (865 nm) variations in the eastern (Donetsk, Lugansk, Kharkiv, Dnipropetrovsk) and western (Lviv, Rivne) regions of Ukraine exhibit two main peaks: the first in the spring (March-April) and the second in the late summer (JulyAugust). The lowest AOD $(865 \mathrm{~nm})$ values are seen in June and in late autumn (Fig. 4). The behavior of AOD (865 nm) in the western part of Ukraine (Lviv) is different and exhibits earlier appearance of spring and summer AOD maxima (Fig. 4d).

The comparison of the AERONET AOD $(870 \mathrm{~nm})$ finemode values with the POLDER AOD $(865 \mathrm{~nm})$ values over the Lugansk site shows their consistent levels and behaviors (Fig. 5). In the Lugansk site the two peaks in season variation of AOD $(870 \mathrm{~nm})$ in total particles are determined by spring maxima in fine and coarse modes and by the JulyAugust maximum of fine-mode (Fig. 5) by the AERONET data. The coarse-mode particle AOD $(870 \mathrm{~nm})$ observed over the Lugansk site has one spring season maximum in AprilMay and minimum in the late autumn (November).

Summary statistics of the all measurements for the AOD and Ångström exponent over different urban-industrial sites and areas of Ukraine are reported in the Supplement Table S1, which describes the averaged aerosol load.

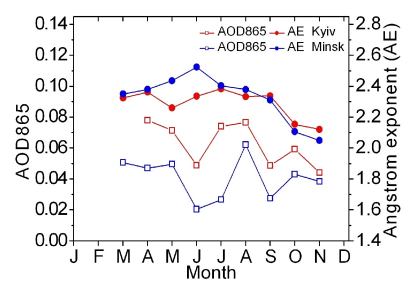

(a)

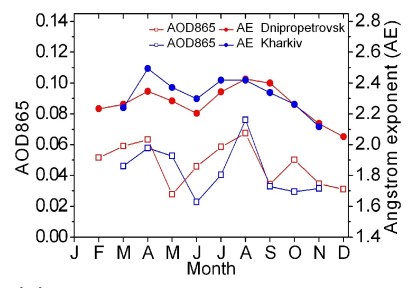

(c)

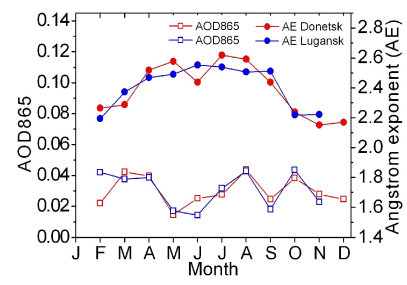

(b)

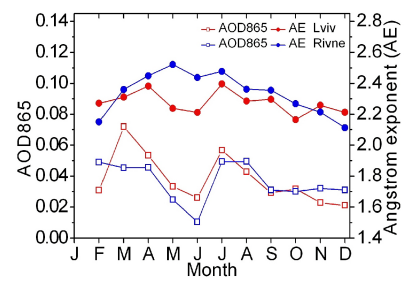

(d)

Figure 4. Seasonal variations of $\mathrm{AOD}(865 \mathrm{~nm})$ values and $\mathrm{AE}$ (670-865 nm) values averaged over 2008-2011 in the atmosphere over the Kyiv, Minsk, Donetsk, Lugansk, Dnipropetrovsk, Kharkiv, Lviv, and Rivne urban-industrial areas based on POLDER data.

\subsection{SSA and refractive index seasonal variability by the Kyiv site data}

The SSA determines the ability of the aerosol particles to scatter the light, and therefore it determines their influence on the solar energy propagation in the Earth's atmosphere. SSA depends on the particle size, shape, chemical composition, and structure. The complex refractive index is defined by the particle chemical composition and structure. The RI together with parameters of particle size distribution are the independent variables in the equations that describe the solar radiation transfer through the atmosphere, and they are determined from the sky almucantar and direct sun AOD measurements in the sun-sky radiance inversion algorithm (Dubovik and King, 2000; Dubovik et al., 2006). The SSA is calculated using the aerosol absorption and scattering coefficients determined from the RI and size distribution. Therefore, the SSA and RI parameters are physically and algorithmically dependent variables.

The estimation of the SSA and RI variations by the Kyiv site data presents the first results for evaluation of aerosol spectral characteristics in the region. The level 2.0 data, which are appropriate for SSA and RI calculation, were not sufficiently collected at the Kyiv site because of weather conditions during period of the observations. For example, the SSA and RI level 2.0 data are absent at the Kyiv site for November-January, one value of the SSA and one of the RI have been obtained only in February, and two values have been obtained only in October during five years of observations. In contrast, from tens to hundreds of the SSA and RI level 1.5 values are available for each year. Therefore, we 


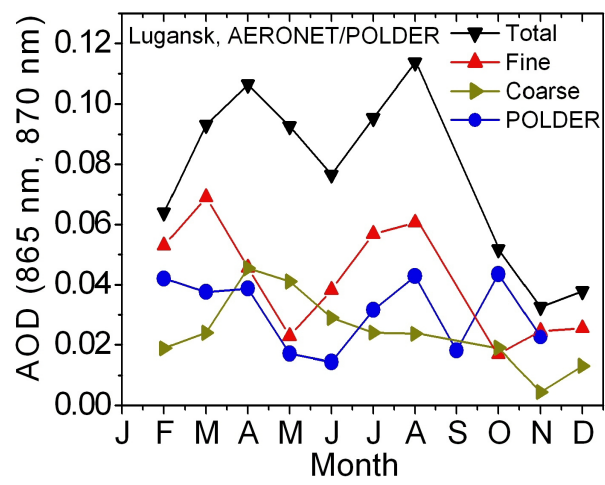

Figure 5. The AOD season variation over Lugansk by the AOD $(870 \mathrm{~nm})$ for total, fine and coarse mode from the AERONET site data and the POLDER AOD $(865 \mathrm{~nm})$ data.

have to use level 1.5 for analysis of the SSA and RI seasonal variability.

We averaged SSA and RI by months over the 2008-2013 period, and it could be expected that possible errors due to a drift of the sun-photometer characteristics would be considered as random values taking into account the replacement of sun photometers at the site each year. Therefore we assume that level 1.5 data are more or less acceptable to reveal seasonality of the SSA and the RI. To estimate reliability of that assumption, we calculated standard deviation (SD) of SSA values and have determined that SD of SSA $(440 \mathrm{~nm})$ is $\pm 0.09(11 \%)$, SD of SSA $(1020 \mathrm{~nm})$ is $\pm 0.12(15 \%)$ in February, and SD is $\pm 0.02(2.5 \%)$ and \pm 0.05 (6.5\%) in July and August, respectively. Resting SD values of the SSA are between these thresholds levels.

The SSA seasonal peculiarities are seen as the spectrum difference between the warm period (April-October) and cold period (November-March). In the warm period, the SSA $(440 \mathrm{~nm})$ value is within the range of $0.89-0.93$, SSA $(1020 \mathrm{~nm})$ within $0.84-0.89$ (Fig. 6a and b), and the SSA decreasing versus wavelength is less sharp than in the cold period. In the cold period the SSA $(440 \mathrm{~nm})$ value is within $0.86-0.82$, and the SSA $(1020 \mathrm{~nm})$ values within $0.79-0.75$, with SD values of \pm 0.07 ( $8 \%$ ) to $\pm 0.10(13 \%)$.

To evaluate the effect of observational selectivity we calculate monthly averaged SSA values for the spring-summer period using level 2.0 data (Fig. 6b). These SSA values are less homogeneous for different wavelengths than level 1.5 data. However, the SSA level 1.5-level 2.0 value difference is within the SD range of the SSA level 1.5 except for the March data, which are explained by the difference in the amount of observations.

Similarly to the SSA parameter behavior, the RI imaginary part $\left(\mathrm{RI}_{\mathrm{im}}\right)$ spectrum exhibits noticeable seasonal difference between warm and cold parts of a year (Fig. 6c). The highest monthly averaged $\mathrm{RI}_{\mathrm{im}}$ values are $0.018 \pm 0.017$ at $440 \mathrm{~nm}$ and $0.022 \pm 0.024$ at $1020 \mathrm{~nm}$ in the warm period. In June, $\mathrm{RI}_{\mathrm{im}}$ values are the lowest: $0.009 \pm 0.005$ at

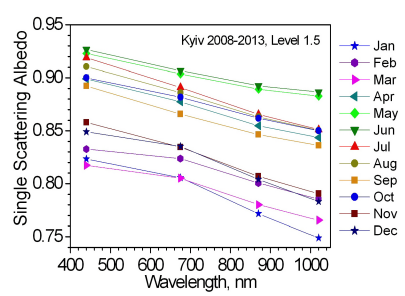

(a)

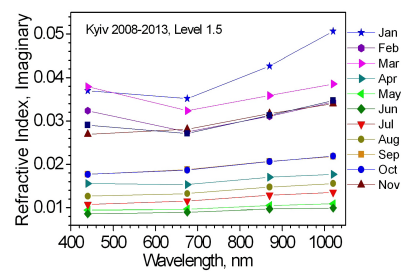

(c)

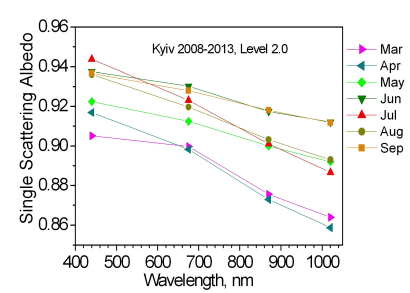

(b)

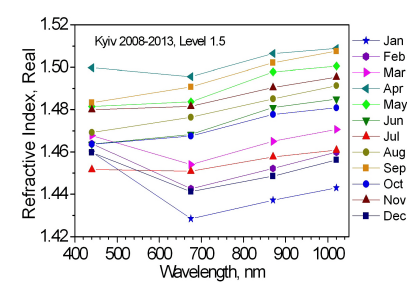

(d)
Figure 6. (a and b) Single-scattering albedo, and (c and d) refractive index spectral dependence by the Kyiv AERONET site data.

$440 \mathrm{~nm}$ and $0.010 \pm 0.008$ at $1020 \mathrm{~nm}$. During NovemberMarch, aerosol particles are defined by relatively large $\mathrm{RI}_{\mathrm{im}}$ values: $0.027-0.037$ at $440 \mathrm{~nm}$ and $0.034-0.051$ at $1020 \mathrm{~nm}$. Since $\mathrm{RI}_{\text {im }}$ defines the absorption ability of the aerosol particles, the $\mathrm{RI}_{\mathrm{im}}$ spectrum seasonal behavior is antisymmetric to the SSA spectrum dependence (see Fig. 6a and c).

The RI real part $\left(\mathrm{RI}_{\mathrm{re}}\right)$ in the average shows seasonal variations similar to the $\mathrm{RI}_{\mathrm{im}}$ values but less distinct (Fig. 6d). The $\mathrm{RI}_{\mathrm{re}}$ monthly averaged spectral characteristics' values during December-March are the lowest in the whole $\mathrm{RI}_{\mathrm{re}}$ range. The shapes of the averaged $\mathrm{RI}_{\mathrm{re}}$ spectral characteristics during this season are similar to the $\mathrm{RI}_{\mathrm{im}}$ spectrum and are mirror-like to the SSA spectrum behavior. This tendency is typical for urban-industrial aerosols according to Dubovik et al. (2002).

\section{Discussions}

\subsection{Seasonal aerosol variations over the Ukraine urban-industrial areas}

Several investigations of aerosol events in the eastern European region reported as the case studies (e.g., Arola et al., 2007; Zawadzka et al., 2014). In our paper we are trying to describe the seasonal aerosol behavior integrated over several years period for Ukrainian regions that is expected to be exposed by urban-industrial aerosol load.

The first spring AOD peak seen in the almost all areas by POLDER data partly can be explained by natural changes in land surface between snow cover in winter and open soil in other seasons, which is accompanied by an increase of soil dust (Sterk and Goossens, 2007; Hinz and Funk, 2007), traffic pollution, and biomass burning aerosol (Stohl et al., 2007; Barnaba et al., 2011) in the atmosphere. The second 
(July-August) peak in AOD values appeared in the averaged data due to frequent wildfires that occurred in the years considered (2008, 2010, 2011; see Fig. 2e). The summer AOD peak for the western part of Ukraine (see Fig. 4d) is shifted to the midsummer (July), relatively to those in eastern and central Ukraine, which agrees well with the results reported by Jaroslawski and Pietruczuk (2010) for the Belsk site (Poland) with fine-mode particle domination (Dubovik et al., 2011). This summer maximum is related to the seasonal biomass burning started earlier in eastern and southern Europe.

According to the AOD $(865 \mathrm{~nm})$ data from the POLDER instrument, the higher levels of aerosol contamination are observed over the Kyiv and Lviv cities in the winter/spring and over Kharkiv in the summer. Surprisingly twice-lower AOD $(865 \mathrm{~nm})$ values were observed over industrial areas Donetsk and Lugansk. However it could be partly explained by selectivity of POLDER data that are mainly represented by fine-mode aerosol. Contamination by coarse-mode fraction in these areas can be significant. This result was confirmed by the Lugansk AERONET site measurements (Fig. 5), where the total aerosol AOD $(870 \mathrm{~nm})$ value is almost the same as in the Kyiv site. The AERONET measurements at the Donetsk site, made episodically in the summer, confirm the significant coarse aerosol mode presence in the data.

The Ångström exponent $(670-865 \mathrm{~nm})$ averaged values have a seasonal trait with two maxima, the first in the spring (April) and the second in the summer (July-August), and a minimum in late autumn for Kyiv, Donetsk, Dnipropetrovsk, Kharkiv, and Lviv areas (see Figs. 2d and 4). In Minsk, Lugansk, and Rivne areas the AE values vary in different ways, increasing from winter months to maximum in midsummer and decreasing in autumn. Therefore we can expect that on average the fine-mode particles are dominant in these areas in summer months. The comparison of AOD $(870 / 865 \mathrm{~nm})$ for the Kyiv and Minsk AERONET sites' data and POLDER data for these two areas shows general agreement in variations and values. There is a difference between AE (440$870 \mathrm{~nm}$, AERONET) and AE (670-865 nm, POLDER) behavior over the Minsk area (Figs. 2d and 4a) with a different period of the summer AE maximum appearance. The AE $(440-870 \mathrm{~nm})$ in Fig. 2d was retrieved from the AERONET total aerosol particles amount, while the AE $(670-865 \mathrm{~nm})$ in Fig. 4a was calculated from the fine-mode particle fraction observed by the POLDER instrument. The different spectral pair line $\mathrm{AE}$ ratio and the $\mathrm{AE}$ dependence on the bi-modal particle size distribution have been investigated by Schuster et al. (2006). They elucidated that spectral variation of aerosol extinction is important in calculations of the AE with two wavelengths only. The results of the AE calculation from the longer wavelength pair $(670-870 \mathrm{~nm})$ are sensitive to the fine-mode aerosol fraction and do not depend on the finemode particle effective radius. The AE calculated from the shorter wavelength pair $(380-440 \mathrm{~nm})$ is more sensitive to the fine-mode effective radius than to the fine-mode fraction (Schuster et al., 2006). Therefore, the AE (440-870 nm)-AE
$(670-865 \mathrm{~nm})$ relationship is explained by the influence of different particle properties.

The amplitude of the seasonal variations in the Sevastopol AERONET site is much smaller in comparison with the Kyiv and Minsk AERONET sites and other investigated Ukrainian areas (Bovchaliuk et al., 2013). This feature is explained by coastal position of the Sevastopol site at the Black Sea and less strong urban and industrial impact than in other Ukraine regions.

\subsection{Seasonal aerosol behavior over the Kyiv site}

The data analysis shows that the aerosol AOD values and volume concentrations in the atmosphere over the Kyiv site are on average larger than over the Minsk site, whereas the AOD seasonal variations are similar (Figs. 2-4). The AOD over both sites exhibits a prominent peak in August and similar variations over the autumn and the winter, with significant deviations from the annual mean in individual years. This seasonal variation is evidence of similarity of the basic aerosol sources in these two regions and is closely related to properties of aerosol particles.

The increased AOD values in the spring and the late summer over the Kyiv site correspond to a relative increase of the aerosol fine-mode particle concentration during each year. In contrast the coarse-mode relative content increases when the AOD decreases in midsummer and winter (see Fig. 3). The AOD (440 nm) maxima both in April and in August appear when the volume concentration values of the fine- and coarse-mode particles are approximately equal (Figs. 2 and $3)$, but in general the AOD $(440 \mathrm{~nm})$ and the AOD $(870 \mathrm{~nm})$ seasonal changes better fit to the fine-mode particle volume concentration seasonal behavior, which explained the SSA and RI values' seasonal changes as well. The AE (440$870 \mathrm{~nm}$ ) variation indicates domination of the fine-mode particles in the AOD $(440 \mathrm{~nm})$ maxima, especially in those that are prominent in Fig. 2d, where the AE was retrieved using the AOD almucantar measurements. The inflection point between fine and coarse mode on the particle volume size distribution (Fig. 7) is varied during the year from $\sim 0.5$ to $\sim 0.9 \mu \mathrm{m}$ with minimum in May over the 2008-2013 period at the Kyiv site (not shown). In general, the fine-mode aerosols define the AOD behavior over the Kyiv site during the year except during May-June (Fig. 2a).

The AE values over the Kyiv site are highest in the midsummer, which can be explained by the domination of the accumulation mode particles in the AOD. The latter determines the AE behavior (see Fig. 2a) due to summer biomass burning and urban-industrial aerosols increasing (Eck et al., 1999). It should be emphasized that the amount of coarsemode particles increases in the period from January to June (Fig. 3a). The noticeable feature is that AOD (440 nm) values in the beginning of the summer (May-June) have practically the same values for each year (Fig. 2e), but the AE values are different (Fig. 2f). 


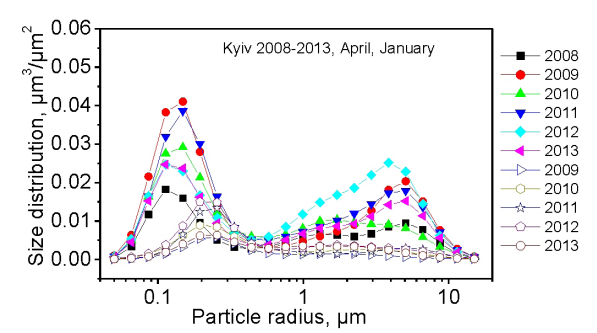

(a)

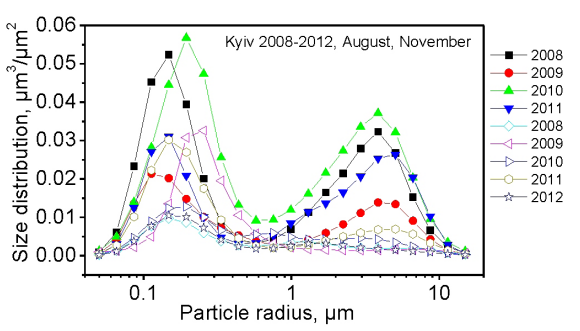

(b)

Figure 7. Monthly mean aerosol particle volume size distribution in the 2008-2013 period for the months that describe (a) maximum AOT $(440 \mathrm{~nm})$ in spring (April, filled symbols) and minimum in winter (January, open symbols); (b) maximum AOT (440 nm) in late summer (August, filled symbols) and minimum in autumn (November, open symbols). The Kyiv AERONET site level 2.0 data.

The Ångström exponent seasonal changes are similar at the Kyiv and Minsk sites, with a peak in midsummer (Kyiv) and the late summer (Minsk), and a minimum in November. These results correspond to fine- and coarse-mode particle behavior in (Fig. 3), where coarse-mode prevails in MayJune over both sites and the fine- and coarse-mode AODs are similar in July-September.

The comparison of the SSA and RI data from the Kyiv AERONET site with results for other European regions allows concluding that aerosol particles over the Kyiv site are of the urban-industrial type according to classification of main aerosol types (e.g., Dubovik et al., 2002; Bergstrom et al., 2007; Giles et al., 2012). The seasonal variations of the SSA and the RI represent particle composition changes; in particular the AOD increase in the spring due to coarsemode particle concentration rise (Figs. 3 and 5) is connected to soil dust raising that corresponds to the raised $\mathrm{RI}_{\mathrm{re}}$ values in April (Fig. 6d).

The analysis of aerosols above Moscow during wildfires in 2010 done by Chubarova et al. (2012) shows that smoke aerosols from forest wildfires also influence the SSA and RI values and their spectral characteristics. That sort of events happened as usual in the warm season. In our analysis we do not exclude these events in data averaging. It should be noted that the SSA and RI are loaded with considerable systematic biases because sky-radiance measurements are impossible on cloudy days. The additional biases arise from break inversion stability criteria that require high aerosol loading conditions when the $\mathrm{RI}_{\mathrm{re}}, \mathrm{RI}_{\mathrm{im}}, \mathrm{SSA}$ retrieval can be more accurate. The aerosol content above the Kyiv site is relatively small: the AOD $(440 \mathrm{~nm})$ exceeds 0.4 only during the special events, like forest fires in 2010.

The monthly mean volume size distributions for the months that represent the season peculiarities - maximum AOT $(440 \mathrm{~nm})$ in the spring (April) and minimum in the winter (January), maximum AOT $(440 \mathrm{~nm})$ in the late summer (August) and minimum in the autumn (November) over 2008-2013 - are presented in Fig. 7. The significant difference in the coarse-mode of the particle size distribution is seen between January and April, and November and August.
In the winter and autumn months the fine-mode particles with modal radii of about $0.2 \mu \mathrm{m}$ prevail and coarse-mode particles are almost not observed. In April over the Kyiv site, the $\mathrm{d} V(r) / \mathrm{d} \ln r$ value of the fine-mode particles is 3 times larger than in January and the particle modal radii is $\sim 0.13 \mu \mathrm{m}$. The coarse-mode particles $(2-5 \mu \mathrm{m})$ with similar content are observed in April and August as well.

To find the potential types of aerosol over the Kyiv AERONET site we created scatter plots (see Fig. 8) of the SSA versus the extinction Angström exponent (EAE) for April and August months separately, the absorption Ångström exponent versus the EAE (440-870 nm), the Ångström exponent (440-870 nm) versus the AOD (440 nm), and the Ångström exponent difference (AE (440-675 nm)$\mathrm{AE}(675-870 \mathrm{~nm}))$ versus $\mathrm{AE}(440-870 \mathrm{~nm})$ according to classifications developed in Dubovik et al. (2002), Omar et al. (2005), Russel et al. (2010), Giles et al. (2012), Boselli et al. (2012), and Yoon et al. (2012).

Analysis of scatter plots in Fig. 8a and b shows that aerosol arrived/measured over the Kyiv AERONET site belongs to the mixture of urban-industrial type mostly and partly to the biomass burning type. Dust particles are not identified according the clustering by aerosol type given in Giles et al. (2012). The seasonal discrimination of Angström exponent difference (AE (440-675 nm)-AE (675-870 nm)) versus AE (440-870 nm) scatter plot may allow dividing particles by the type prevailing in each season (Fig. $8 \mathrm{c}$ and the Supplement Fig. S1).

According to a classification proposed by Yoon et al. (2012) the fine-mode urban-industrial aerosols in winter months (DJF) are observed with small presence of dust coarse-mode particles. In spring months (MAM) the urbanindustrial type and dust coarse-mode aerosol are observed including a smaller-amount biomass burning type. In summer months (JJA) the fine-mode urban-industrial aerosol is dominant and the biomass burning type aerosol is observed in contrast to SON. In autumn months (SON) urban-industrial and mixed type of aerosol is dominant; however, the other type of aerosol particles appeared in the SON period only in segment with the AE-difference / $\mathrm{AE}$ ratio equal to about 


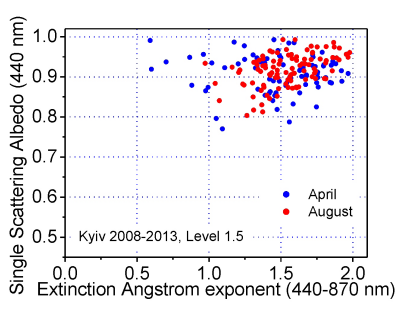

(a)

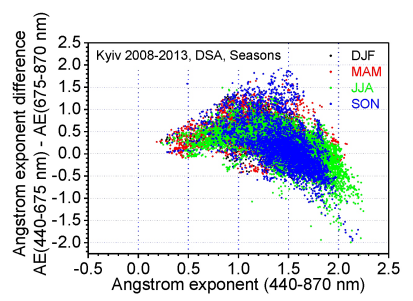

(c)

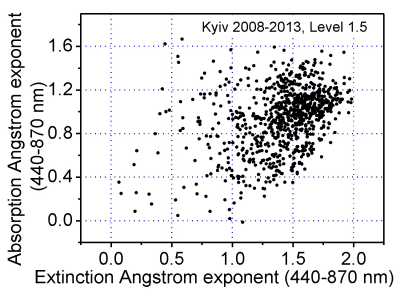

(b)

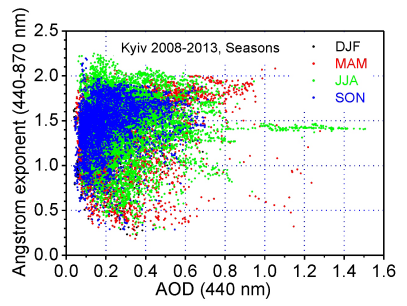

(d)

Figure 8. (a) Scatter plot SSA versus extinction Ångström exponent (EAE) for April and August months separately, (b) absorption Ångström exponent versus EAE (440-870 nm). (c) Seasonal scatter plot Ångström exponent difference (AE (440-675 nm)AE (675-870 nm)) versus Ångström exponent (440-870 nm), and (d) Ångström exponent (440-870 nm) versus AOD (440 nm). Data from the Kyiv AERONET site.

1.5/1.5, which is not included in the Yoon et al. (2012) classification (see Fig. 8c and Fig. S1).

The analysis of the seasonal differentiation of the $\mathrm{AE}$ (440-870 nm) versus AOD (440 nm) scatter plot allows assuming the seasonal features of aerosol particles over Kyiv (Fig. 8d and the Supplement Fig. S2). In DJF the AOD $(440 \mathrm{~nm})$ values are on average less than $\sim 0.4$. The finemode particles with $\mathrm{AE}>1.8$ are not observed in the winter season. In the spring only the coarse-mode particles with $\mathrm{AE}<0.5$ and $\mathrm{AOD}(440 \mathrm{~nm}) \sim 0.1-1.1$ are measured, and fine-mode particles with $\mathrm{AE} \sim 1.8$ and AOD $(440 \mathrm{~nm})$ up to 0.9 are measured. A small amount of the fine-mode fraction dust with $\mathrm{AE}>2$ is observed in summer months. The event of wildfire in Russia (Chubarova et al., 2012) in midAugust 2010 seen well as a chain of data with $\mathrm{AE} \sim 1.4$ and AOD $(440 \mathrm{~nm})$ up to $\sim 1.5$ as the result of the biomass burning smoke particles arrived at the Kyiv site on 1516 August 2010. The autumn AE/AOT $(440 \mathrm{~nm})$ distribution is similar to the spring scatter plot except for the smaller amount of fine-mode (AE > 1.8) and coarse-mode ( $\mathrm{AE}<0.5)$ particles. The scatter plots data correspond to results of the AOD and Ångström exponent seasonal traits in Fig. 2: minimal AOD values in the winter and in the autumn and maximum ones in the summer.

We applied the back-trajectory and cluster analysis methods to calculate the seasonal back trajectories and prevailing directions of the arrived air mass for the Kyiv and Minsk sites to investigate the possible seasonal variations of aerosol.
The 3-D back trajectories over the 2012-2013 period for the Kyiv site and over the 2008-2013 period for the Minsk site have been downloaded from the AERONET website. The back trajectories over the 2008-2011 period for the Kyiv site we calculated using the software developed in Burak et al. (2010). The wind field and temperature data from the Belarus Hydrometeorology Center (http://hmc.by/) were used for calculation.

The calculated trajectory presents the pathway of air mass transported at the height of about $1.5 \mathrm{~km}(850 \mathrm{hPa})$ during $48 \mathrm{~h}$ before measurement. The cluster analysis produced the five cluster trajectories with prevailing directions averaged by seasons over the period 2008-2013. The trajectories in day of measurement (red lines) at the Kyiv and Minsk AERONET sites and the seasonal cluster trajectories from five prevailing directions (bold blue lines) are shown in the Supplement Fig. S3. For each season we determined the most prevailing trajectory that is responsible for arrived aerosol. This trajectory is described by fraction $N$ of the trajectories number in the main cluster to the number of trajectories in all five clusters. The most prevailing trajectories for the Kyiv and Minsk sites in each season are shown in Table 2.

We consider a possibility to determine the presence of the Saharan dust by the Kyiv and Minsk site data. According to Israelevich et al. (2012) the events with the high AOD values in the European region are associated with biomass burning, anthropogenic pollution, soil erosion, and transported dust from Saharan sources. All of these events are expected to exhibit seasonal variations. For the eastern Mediterranean three periods of increased atmospheric dust were observed: in spring (March-May), in summer (July-August), and in autumn (September-November). Results of ten years (2001-2010) of MODIS data analysis of the seasonal variations of Saharan dust transport over the Mediterranean to Europe (Israelevich et al., 2012) show AOD seasonal increase in April and July-September at the Kyiv longitude similar to our results in Fig. 2. Papayannis et al. (2008) reported on Saharan dust event observations on about 20 days by Minsk lidar measurements over the 2000-2002 period. Saharan dust intrusions in the eastern Mediterranean and Europe are most active in the spring season (Barnaba and Gobbi, 2004; Papayannis et al., 2008). Therefore we can expect the appearance of Saharan dust to the Kyiv and Minsk sites in 2008-2013. According to seasonal back trajectories the most favorable conditions for dust aerosol transport from the eastern Mediterranean region exist in the spring and in the autumn. The spectral aerosol parameters SSA and RI in spring months (Fig. 6) are close to those reported by Kim et al. (2011) for dust aerosol. Moreover, the SSA spectrum in May 2008 (not shown) exhibits similar spectral variation and values to the desert dust aerosols classified by Dubovik et al. (2002). Aerosol particles with parameters $\mathrm{AE}<0.5$ and AOD $(440 \mathrm{~nm})>0.4$ are observed at the Kyiv site in the spring and summer months (Fig. 8d and the Supplement Fig. S2b and c) that correspond to dust type aerosols 
Table 2. The most prevailing seasonal trajectory for the Kyiv and Minsk sites calculated using the back trajectories and cluster analysis.

\begin{tabular}{|c|c|c|c|c|}
\hline \multirow[b]{2}{*}{ Season/AERONET site } & \multicolumn{2}{|c|}{ Kyiv } & \multicolumn{2}{|c|}{ Minsk } \\
\hline & Direction & Fraction $N$ & Direction & Fraction $N$ \\
\hline Winter & North & $25 / 87$ & Northeast & $31 / 107$ \\
\hline Spring & West & $223 / 753$ & Northwest & $158 / 570$ \\
\hline Summer & West & $170 / 709$ & West & $125 / 482$ \\
\hline Autumn & South & $167 / 424$ & East & $57 / 159$ \\
\hline
\end{tabular}

described by Pavese et al. (2012). Therefore the Saharan mineral dust that often extended across the Mediterranean into Europe (Papayannis et al., 2008; Israelevich et al., 2012) is transported to the eastern European region mostly in the late summer and autumn (August-September) and infrequently in the spring (April). This inference is confirmed by increasing of the RI real part in these months that corresponds to the mineral particle composition increase (Fig. 6).

\section{Conclusions}

The seasonal variations of aerosol amount and optical properties over several Ukrainian urban-industrial areas are analyzed using the ground-based data from AERONET sun photometers and POLDER satellite instrument data. We investigate the aerosol seasonal behavior over the areas of the cities Kyiv, Lugansk, Donetsk, Kharkiv, Dnipropetrovsk, Lviv, and Rivne and the area of the Belarus city Minsk for comparison to Kyiv. These areas are influenced by numerous local aerosol pollution sources (intensive city transport, heavy industry) and by the aerosol transport from remote sources (open steppe fields, mining, and wildfires).

We extracted the monthly averaged AOD at 440 and $870 \mathrm{~nm}$ and the Ångström exponent values for the 440$675 \mathrm{~nm}$ and $440-870 \mathrm{~nm}$ channels from the AERONET database for the Kyiv, Minsk, and Lugansk sites. Also the size distribution and volume concentration, the SSA and complex RI, the absorption AOD and the extinction AOD retrieved by AERONET inversion algorithm were used for aerosol behavior analysis at the Kyiv site. The monthly mean $A O D$ values at $865 \mathrm{~nm}$ and the AE values at $670 / 865 \mathrm{~nm}$ were derived from POLDER measurements. The comparison of the AERONET and POLDER data shows that AOD $(865 \mathrm{~nm})$ determined from POLDER measurements are lower than AOD $(870 \mathrm{~nm})$ from AERONET measurements because POLDER data are determined by fine-mode particles in contrast to AERONET total (fine and coarse modes) particle AOD.

We reveal the similar behavior of average aerosol parameter values in all areas of the eastern and central part of Ukraine where measurements were performed using both AERONET and POLDER techniques: the aerosol amount and the optical thickness values exhibit peaks in the spring
(April-May) and the late summer (August), whereas minimum values are seen in the late autumn. The summer AOD maximum is larger in the Kyiv and Minsk sites, and minimum aerosol content is reached in the late autumn. The behavior of the aerosol parameters in the western part of Ukraine is different from eastern and central regions and exhibits an earlier appearance of spring and summer AOD maxima. This aerosol behavior in general agrees with the results achieved by other authors, e.g., Sayer et al. (2012) on seasonal variations in the Eurasian region and by Pietruczuk and Chaikovsky (2012), who suggested also that biomass burning products and Saharan dust are responsible for large AOD values during the spring time in this area.

The aerosol particle volume concentrations over the Kyiv and Minsk sites have two maxima during the warm part of a year. The AOD and the total, as well as fine- and coarsemode volume concentration of the particles over the Minsk site have the same as in the Kyiv site trend during all months except July and December, and two maxima: in April-May and in August. The correspondence of these values exists in general also in the case of the Kyiv site, but the total particle volume concentration over Kyiv reaches maximum in June simultaneously with the volume concentration of the coarsemode particle maximum, whereas the AOD maximum comes in April simultaneously with the fine-mode particle volume concentration maximum. The total volume concentration has its minimum in winter months, when fine-mode particles prevail.

On average, the aerosol amount over the Kyiv site is larger than that over the Minsk site in the summer and in the early autumn. The load of fine-mode particle content over Minsk is larger than over the Kyiv site during almost all seasons.

To reveal the aerosol particle microphysics seasonal behavior and to estimate the aerosol type, the SSA and RI values and spectra at the Kyiv AERONET site were analyzed. The SSA monthly averaged spectra are divided into two groups: during warm period (April-October) they have higher values and relatively smooth and monotonous shapes, whereas during cold period the SSA values are lower and shapes are more tilted, bended and more various. The monthly averaged RI spectra also are different in warm and cold parts of a year. Specifically the RI imaginary part values and spectra have sharp difference for the seasons and are mirror-like to the SSA spectrum behavior. The 
monthly averaged spectral characteristics of the $\mathrm{RI}_{\mathrm{re}}$ during December-March are in the lowest part of the range. The SSA and refractive index values and spectra correspond to a mix of urban-industrial, biomass burning, and dust aerosols.

The amount of coarse-mode particles in the atmosphere above the investigated Ukrainian areas during the warm period of a year exceeds, on average, twice their amount during the cold period. We consider that as an effect of large open land areas in the south of Ukraine and in the southeastern European part of Russia where dust storms are frequent during the warm period, whereas during the cold period these areas are mostly covered by snow preventing dust uplift.

We create scatter plots of the different aerosol parameters using the Kyiv site data to evaluate the potential types of aerosol. According to a classification proposed by Yoon et al. (2012), in winter months the fine-mode urban-industrial aerosols are observed with small presence of the dust coarsemode particles. In spring months the urban-industrial type and dust coarse-mode aerosol are observed including the smaller-amount biomass burning type. In summer months the fine-mode urban-industrial aerosol is dominant and the biomass burning type aerosol is observed. In autumn months urban-industrial and mixed type of aerosol is dominant; however, the other type of aerosol particles appeared in the SON period only in segment with the AE-difference / AE ratio, which is not described in the Yoon et al. (2012) classification. The scatter plot data in general correspond with results of the AOD and Ångström exponent seasonal traits, with the low AOD values in the winter and in the autumn and large AOD in the spring and the summer. This seasonal behavior is explained by the influence of the local sources as well as by aerosol transport. According to back-trajectory analysis the industrial type aerosol particles are transported mainly from the western Europe regions in the spring and in the summer.

The presence of the Saharan dust was investigated using the Kyiv site data. According to seasonal back trajectories the most favorable conditions for dust aerosol transport from the eastern Mediterranean region, which experienced frequent Saharan dust intrusions, exist in the spring and the autumn. The spectral aerosol parameters (SSA, RI) measured at the Kyiv site in spring and in summer months comply with the dust type particles (Kim et al., 2011; Pavese et al., 2012). Therefore, we can assume that the Saharan mineral dust extending across the Mediterranean into Europe (Israelevich et al., 2012) is possibly transported to the Ukrainian areas mostly in the late summer and autumn (August-September) and infrequently in the spring.

\section{The Supplement related to this article is available online} at doi:10.5194/amt-7-1459-2014-supplement.
Acknowledgements. The work was supported by award no. UKG22969-KV-09 from the US Civilian Research and Development Foundation (CRDF), by the project PICS 2013-2015 of CNRS and NASU, the project 11BF051-01-12 of Taras Shevchenko National University of Kyiv, by the Special Complex Program for Space Research 2012-2016 of the National Academy of Sciences of Ukraine, and the NASA Radiation Sciences Program managed by Hal Maring. We thank B. Holben (NASA/GSFC) for managing the AERONET program and its sites. We appreciate the effort in establishing and maintaining AERONET Lugansk site by V. Voytenko. The authors thank the ICARE Data and Services Center team for providing access to the PARASOL data and for general assistance and processing support. Authors thank T. Kucsera (GESTAR/USRA) at NASA/Goddard for back trajectories available at the aeronet.gsfc.nasa.gov website. The high quality of AERONET/PHOTONS data was provided by CIMEL sun-photometer calibration performed at LOA using the AERONET-EUROPE calibration center, supported by ACTRIS of the European Union's Seventh Framework Programme (FP7/20072013) under grant agreement no. 262254.

Edited by: A. Kokhanovsky

\section{References}

Alexandrov, M. D., Lacis, A. A., Carlson, B. E., and Cairns, B.: Remote Sensing of Atmospheric Aerosols and Trace Gases by Means of Multifilter Rotating Shadowband Radiometer. Part I: Retrieval Algorithm, J. Atmos. Sci., 59, 524-543, 2002a.

Alexandrov, M. D., Lacis, A. A., Carlson, B. E., and Cairns, B.: Remote Sensing of Atmospheric Aerosols and Trace Gases by Means of Multifilter Rotating Shadowband Radiometer. Part II: Climatological Applications, J. Atmos. Sci., 59, 544-566, 2002b.

Amiridis, V., Giannakaki, E., Balis, D. S., Gerasopoulos, E., Pytharoulis, I., Zanis, P., Kazadzis, S., Melas, D., and Zerefos, C.: Smoke injection heights from agricultural burning in Eastern Europe as seen by CALIPSO, Atmos. Chem. Phys., 10, 1156711576, doi:10.5194/acp-10-11567-2010, 2010.

Anderson, T. L., Charlson, R. J., Bellouin, N., Boucher, O., Chin, M., Christopher, S. A., Haywood, J., Kaufman, Y. J., Kinne, S., Ogren, J. A., Remer, L. A., Takemura, T., Tanré, D., Torres, O., Trete, C. R., Wielicki, B. A., Winker, D. M., and Yu, H.: An "ATrain" strategy for quantifying direct climate forcing by anthropogenic aerosols, B. Am. Meteorol. Soc., 86, 1795-1809, 2005.

Andrews, E., Sheridan, P. J., and Ogren, J. A.: Seasonal differences in the vertical profiles of aerosol optical properties over rural Oklahoma, Atmos. Chem. Phys., 11, 10661-10676, doi:10.5194/acp-11-10661-2011, 2011.

Arola, A., Lindfors, A., Natunen, A., and Lehtinen, K. E. J.: A case study on biomass burning aerosols: effects on aerosol optical properties and surface radiation levels, Atmos. Chem. Phys., 7, 4257-4266, doi:10.5194/acp-7-4257-2007, 2007.

Barnaba, F. and Gobbi, G. P.: Aerosol seasonal variability over the Mediterranean region and relative impact of maritime, continental and Saharan dust particles over the basin from MODIS data in the year 2001, Atmos. Chem. Phys., 4, 2367-2391, doi:10.5194/acp-4-2367-2004, 2004.

Barnaba, F., Angelini, F., Curci, G., and Gobbi, G. P.: An important fingerprint of wildfires on the European aerosol load, 
Atmos. Chem. Phys., 11, 10487-10501, doi:10.5194/acp-1110487-2011, 2011.

Bergstrom, R. W., Pilewskie, P., Russell, P. B., Redemann, J., Bond, T. C., Quinn, P. K., and Sierau, B.: Spectral absorption properties of atmospheric aerosols, Atmos. Chem. Phys., 7, 5937-5943, doi:10.5194/acp-7-5937-2007, 2007.

Birmili, W., Schepanski, K., Ansmann, A., Spindler, G., Tegen, I., Wehner, B., Nowak, A., Reimer, E., Mattis, I., Müller, K., Brüggemann, E., Gnauk, T., Herrmann, H., Wiedensohler, A., Althausen, D., Schladitz, A., Tuch, T., and Löschau, G.: A case of extreme particulate matter concentrations over Central Europe caused by dust emitted over the southern Ukraine, Atmos. Chem. Phys., 8, 997-1016, doi:10.5194/acp-8-997-2008, 2008.

Boersma, K. F., Eskes, H. J., and Brinksma E. J.: Error analysis for tropospheric $\mathrm{NO}_{2}$ retrieval from space, J. Geophys. Res., 109, D04311, doi:10.1029/2003JD003962, 2004.

Boersma, K. F., Eskes, H. J., Dirksen, R. J., van der A, R. J., Veefkind, J. P., Stammes, P., Huijnen, V., Kleipool, Q. L., Sneep, M., Claas, J., Leitão, J., Richter, A., Zhou, Y., and Brunner, D.: An improved tropospheric $\mathrm{NO}_{2}$ column retrieval algorithm for the Ozone Monitoring Instrument, Atmos. Meas. Tech., 4, 19051928, doi:10.5194/amt-4-1905-2011, 2011.

Boselli, A., Caggiano, R., Cornacchia, C., Madonna, F., Mona, L., Macchiato, M., Pappalardo, G., and Trippetta, S.: Multi year sunphotometer measurements for aerosol characterization in a Central Mediterranean site, Atmos. Res., 104-105, 98-110, 2012.

Bovchaliuk, A., Milinevsky, G., Danylevsky, V., Goloub, P., Dubovik, O., Holdak, A., Ducos, F., and Sosonkin, M.: Variability of aerosol properties over Eastern Europe observed from ground and satellites in the period from 2003 to 2011, Atmos. Chem. Phys., 13, 6587-6602, doi:10.5194/acp-13-6587-2013, 2013.

Bréon, F.-M.: Parasol Level-1 Product Data Format and User Manual. CEA/LSCE, CNES, France, 31 pp., 2006.

Bréon, F.-M. and Colzy, S.: Cloud Detection from the Spaceborne POLDER Instrument and Validation against Surface Synoptic Observations, J. Appl. Meteor., 38, 777-785, doi:10.1175/15200450(1999)038<0777:CDFTSP>2.0.CO;2, 1999.

Bréon, F.-M., Vermeulen, A., and Descloitres, J.: An evaluation of satellite aerosol products against sunphotometer measurements, Remote Sens. Environ., 115, 3102-3111, doi:10.1016/j.rse.2011.06.017, 2011.

Burak, R. N., Dementsova, I. A., Kabashnikov, V. P., and Metelskaya, N. S.: TRAJECTORY - software for air mass trajectory calculation. Systema upravleniya ekologicheskoj bezopasnostyu. Proceedings IV International Scientific-Practical Meeting, Ekaterinburg, 27-28 May 2010, 2, 127-131, 2010.

Burrows, J. P., Dehn, A., Deters, B., Himmelmann, S., Richter, A., Voigt, S., and Orphal, J.: Atmospheric remote-sensing reference data from GOME: Part 1. Temperature-dependent absorption cross-sections of $\mathrm{NO}_{2}$ in the 231-794 nm range, J. Quant. Spectrosc. Ra., 60, 1025-1031, 1998.

Cairns, B., Waquet, F., Knobelspiesse, K., Chowdhary, J., and Deuzé, J.-L.: Polarimetric remote sensing of aerosols over land surfaces, in: Satellite Aerosol Remote Sensing over Land, edited by: Kokhanovsky, A. A. and De Leeuw, G., Springer, 295-325, doi:10.1007/978-3-540-69397-0_10, 2009.
Chubarova, N. Y.: Seasonal distribution of aerosol properties over Europe and their impact on UV irradiance, Atmos. Meas. Tech., 2, 593-608, doi:10.5194/amt-2-593-2009, 2009

Chubarova, N., Nezval', Ye., Sviridenkov, I., Smirnov, A., and Slutsker, I.: Smoke aerosol and its radiative effects during extreme fire event over Central Russia in summer 2010, Atmos. Meas. Tech., 5, 557-568, doi:10.5194/amt-5-557-2012, 2012.

Danylevsky, V., Ivchenko, V., Milinevsky, G., Grytsai, A., Sosonkin, M., Goloub, Ph., Li, Z., and Dubovik, O.: Aerosol layer properties over Kyiv from AERONET/PHOTONS sunphotometer measurements during 2008-2009, Int. J. Remote Sens., 32, 657-669, doi:10.1080/01431161.2010.517798, 2011.

Deschamps, P. Y., Bréon, F. M., Leroy, M., Podaire, A., Bricaud, A., Buriez, J. C., and Sèze, G.: The POLDER Mission: Instrument Characteristics and Scientific Objectives, IEEE T. Geosci. Remote, 32, 598-615, 1994.

Deuzé, J.-L., Bréon, F.-M., Devaux, C., Goloub, P., Herman, M., Lafrance, B., Maignan, F., Marchand, A., Perry, G., and Tanré, D.: Remote Sensing of aerosols over land surfaces from POLDER/ADEOS-1 polarized measurements, J. Geophys. Res., 106, 4913-4926, doi:10.1029/2000JD900364, 2001.

Dubovik, O. and King, M.: A flexible inversion algorithm for retrieval of aerosol optical properties from Sun and sky radiance measurements, J. Geophys. Res., 105, 20673-20696, 2000.

Dubovik, O., Smirnov, A., Holben, B. N., King, M. D., Kaufman, Y. J., Eck, T. F., and Slutsker I.: Accuracy assessments of aerosol optical properties retrieved from Aerosol Robotic Network (AERONET) Sun and sky radiance measurements, J. Geophys. Res., 105, 9791-9806, 2000.

Dubovik, O., Holben, B. N., Eck, F. T., Smirnov, A., Kaufman, J. Y., King, D. M., Tanré, D., and Slutsker, I.: Variability of absorption and optical properties of key aerosol types observed in worldwide locations, J. Atmos. Sci., 59, 590-608, 2002.

Dubovik, O., Sinyuk, A., Lapyonok, T., Holben, B. N., Mishchenko, M., Yang, P., Eck, T. F., Volten, H., Munoz, O., Veihelmann, B., van der Zande, W. J., Leon, J.-F., Sorokin, M., and Slutsker, I.: Application of spheroid models to account for aerosol particle nonsphericity in remote sensing of desert dust, J. Geophys. Res., 111, D11208, doi:10.1029/2005JD006619, 2006.

Dubovik, O., Herman, M., Holdak, A., Lapyonok, T., Tanré, D., Deuzé, J. L., Ducos, F., Sinyuk, A., and Lopatin, A.: Statistically optimized inversion algorithm for enhanced retrieval of aerosol properties from spectral multi-angle polarimetric satellite observations, Atmos. Meas. Tech., 4, 975-1018, doi:10.5194/amt-4975-2011, 2011.

Eck, T. F., Holben, B. N., Reid, J. S., Dubovik, O., Smirnov, A., O'Neill, N. T., Slutsker, I., and Kinne, S.: Wavelength dependence of the optical depth of biomass burning, urban, and desert dust aerosols, J. Geophys. Res., 104, 31333-31349, doi:10.1029/1999JD900923, 1999.

Enhalt, D., Prather, M., Dentener, F., Derwent, R., Dlugokencky, E., Holland, E., Isaksen, I., Katima, J., Kirchhoff, V., Matson, P., Midgley, P., and Wang, M.: Climate Change 2001: The Scientific Basis. Contribution of Working Group I to the Third Assessment Report of the Intergovernmental Panel on Climate Change, edited by: Houghton, J. T., Ding, Y., Griggs, D. J., Noguer, M., van der Linden, P. J., Dai, X., Maskell, K., and Johnson, C. A., Cambridge University Press, Cambridge, United Kingdom and New York, NY, USA, 881 pp., 2001. 
Fan, X., Goloub, P., Deuzé, J.-L., Chen, H., Zhang, W., Tanré, D., and Li, Z.: Evaluation of PARASOL aerosol retrieval over North East Asia, Remote Sens. Environ., 112, 697-707, doi:10.1016/j.rse.2007.06.010, 2008.

Gerasopoulos, E., Koulouri, E., Kalivitis, N., Kouvarakis, G., Saarikoski, S., Mäkelä, T., Hillamo, R., and Mihalopoulos, N.: Size-segregated mass distributions of aerosols over Eastern Mediterranean: seasonal variability and comparison with AERONET columnar size-distributions, Atmos. Chem. Phys., 7, 2551-2561, doi:10.5194/acp-7-2551-2007, 2007.

Giles, D. M., Holben, B. N., Eck, T. F., Sinyuk, A., Smirnov, A., Slutsker, I., Dickerson, R. R., Thompson, A. M., and Schafer, J. $S$ : An analysis of AERONET aerosol absorption properties and classifications representative of aerosol source regions, J. Geophys. Res., 117, D17203, doi:10.1029/2012JD018127, 2012.

Goloub, P., Tanré, D., Deuzé, J. L., Herman, M., Marchand, A., Bréon, F.-M.: Validation of the first algorithm applied for deriving the aerosol properties over the ocean using the POLDER/ADEOS measurements, IEEE T. Geosci. Remote, 37, 1586-1596, doi:10.1109/36.763270, 1999.

Hara, K., Osada, K., Nishita-Hara, C., and Yamanouchi, T.: Seasonal variations and vertical features of aerosol particles in the Antarctic troposphere, Atmos. Chem. Phys., 11, 5471-5484, doi:10.5194/acp-11-5471-2011, 2011.

Hara, K., Osada, K., and Yamanouchi, T.: Tethered balloon-borne aerosol measurements: seasonal and vertical variations of aerosol constituents over Syowa Station, Antarctica, Atmos. Chem. Phys., 13, 9119-9139, doi:10.5194/acp-13-9119-2013, 2013.

Herman, M., Deuzé, J. L., Marchand, A., Roger, B., and Lallart, P.: Aerosol remote sensing from POLDER/ADEOS over the ocean: Improved retrieval using a nonspherical particle model, J. Geophys. Res., 110, D10S02, doi:10.1029/2004JD004798, 2005.

Hinz, T. and Funk, R.: Particle emissions of soils induced by agricultural field operations, DustConf International Conference, Maastricht, Netherlands, 23-24 April 2007, 10 pp., 2007.

Holben, B. N., Eck, T. F., Slutsker, I., Tanré, D., Buis, J. P., Setzer, A., Vermote, E., Reagan, J. A., Kaufman, Y. J., Nakajima, T., Lavenu, F., Jankowiak, I., and Smirnov, A.: AERONET - a federated instrument network and data archive for aerosol characterization, Remote Sens. Environ., 66, 1-16, 1998.

Israelevich, P., Ganor, E., Alpert, P., Kishcha, P., and Stupp, A.: Predominant transport paths of Saharan dust over the Mediterranean Sea to Europe, J. Geophys. Res., 117, D02205, doi:10.1029/2011JD016482, 2012.

Jaroslawski, J. and Pietruczuk, A.: On the origin of seasonal variation of aerosol optical thickness in UV range over Belsk, Poland, Acta Geophys., 58, 1134-1146, doi:10.2478/s11600-010-00194, 2010.

Kaufman, Y., Boucher, O., Tanré, D., Chin, M., Remer, L., and Takemura, T.: Aerosol anthropogenic component estimated from satellite data, Geophys. Res. Lett., 32, L17804.1-L17804.4, 2005.

Kim, D., Chin, M., Yu, H., Eck, T. F., Sinyuk, A., Smirnov, A., and Holben, B. N.: Dust optical properties over North Africa and Arabian Peninsula derived from the AERONET dataset, Atmos. Chem. Phys., 11, 10733-10741, doi:10.5194/acp-1110733-2011, 2011.
King, M. D., Kaufman, Y. J., Tanré, D., and Nakajima, T.: Remote Sensing of Tropospheric Aerosols from Space: Past, Present, and Future, B. Am. Meteorol. Soc., 80, 2229-2259, 1999.

Kokhanovsky, A. A.: Aerosol optics. Light absorption and scattering by particles in the atmosphere. Springer, 146 pp., 2008.

Kokhanovsky, A. A., Bréon, F.-M., Cacciari, A., Diner, D., Di Nicolantonio, W., Grainer, R. G., Grey, W. M. F., Höller, R., Lee, K.-H., Li, Z., North, P. R. J., Sayer, A. M., Thomas, G. E., and von Hoyningen-Uuene, W.: Aerosol remote sensing over land: A comparison of satellite retrievals using different algorithms and instruments, Atmos. Res., 85, 372-394, 2007.

Leskinen, A., Arola, A., Komppula, M., Portin, H., Tiitta, P., Miettinen, P., Romakkaniemi, S., Laaksonen, A., and Lehtinen, K. E. J.: Seasonal cycle and source analyses of aerosol optical properties in a semi-urban environment at Puijo station in Eastern Finland, Atmos. Chem. Phys., 12, 5647-5659, doi:10.5194/acp-12-56472012, 2012.

Li, Z., Zhao, X., Kahn, R., Mishchenko, M., Remer, L., Lee, K.-H., Wang, M., Laszlo, I., Nakajima, T., and Maring, H.: Uncertainties in satellite remote sensing of aerosols and impact on monitoring its long-term trend: a review and perspective, Ann. Geophys., 27, 2755-2770, doi:10.5194/angeo-27-2755-2009, 2009.

Liu, J., Zheng, Y., Li, Zh., Flynn, C., and Cribb, M.: Seasonal variations of aerosol optical properties, vertical distribution and associated radiative effects in the Yangtze Delta region of China, J. Geophys. Res., 117, 2156-2202, doi:10.1029/2011JD016490, 2012.

Milinevsky, G. P.: The AERONET network: atmospheric aerosol research in Ukraine, Bulletin of Ukrainian Earth Orientation Parameters Laboratory (BUEOP), 8, 95-97, 2013.

Milinevsky, G. P., Danylevsky, V. O., Grytsai, A. V., Evtushevsky, O. M., Kravchenko, V. O., Bovchaliuk, A. P., Bovchaliuk, V. P., Sosonkin, M. G., Goloub, Ph., Savitska, L. Y., Udodov, E. V., and Voytenko, V. P.: Recent development of atmosphere research in Ukraine, Adv. Astron. Space Phys., 2, 114-120, 2012.

Mishchenko, M. I., Cairns, B., Kopp, G., Schueler, C. F., Fafaul, B. A., Hansen, J. E., Hooker, R. J., Itchkawich, T., Maring, H. B., and Travis, L. D.: Accurate monitoring of terrestrial aerosol and total solar irradiance: Introducing the GLORY mission, B. Am. Meteorol. Soc., 80, 2229-2259, 2007.

Mishchenko, M. I., Liu, L., Geogdzhayev, I. V., Travis, L. D., Cairns, B., and Lacis, A. A.: Toward unified satellite climatology of aerosol properties. 3. MODIS versus MISR versus AERONET, J. Quant. Spectrosc. Ra., 111, 540-552, 2010.

Ogunjobi, K. O., He, Z., and Simmer C.: Spectral aerosol optical properties from AERONET Sun-photometric measurements over West Africa, Atmos. Res., 88, 89-107, 2008.

Omar, A. H., Won, J.-G., Winker, D. M., Yoon, S.-C. , Dubovik, O., and McCormick, M. P.: Development of global aerosol models using cluster analysis of Aerosol Robotic Network (AERONET) measurements, J. Geophys. Res., 110, D10S14, doi:10.1029/2004JD004874, 2005.

Papayannis, A., Amiridis, V., Mona, L., Tsaknakis, G., Balis, D., Bosenberg, J., Chaikovski, A., De Tomasi, F., Grigorov, I., Mattis, I., Mitev, V., Muller, D., Nickovic, S., Perez, C., Pietruczuk, A., Pisani, G., Ravetta, F., Rizi, V., Sicard, M., Trickl, T., Wiegner, M., Gerding, M., Mamouri, R. E., D’Amico, G., and Pappalardo, G.: Systematic lidar observations of Saharan dust over 
Europe in the frame of EARLINET (2000-2002), J. Geophys. Res., 113, D10204, doi:10.1029/2007JD009028, 2008.

Pavese, G., Calvello, M., Esposito, F., Leone, L., and Restieri, R.: Effects of Saharan dust advection on atmospheric aerosol properties in the West-Mediterranean area, Adv. Meteorol., 2012, 730579, doi:10.1155/2012/730579, 2012.

Pietruczuk, A. and Chaikovsky, A.: Variability of aerosol properties during the 2007-2010 spring seasons over central Europe, Acta Geophys., 60, 1338-1358, doi:10.2478/s11600-012-00179, 2012.

Rana, S., Kant, Y., and Dadhwal, V. K.: Diurnal and seasonal variation of spectral properties of aerosols over Dehradun, India, Aerosol Air Qual. Res., 9, 32-49, 2009.

Rublev, A. N., Chubarova, N. E., Trotsenko, A. N., and Gorchakov, G. I.: Determination of $\mathrm{NO}_{2}$ Column Amounts from AERONET Data, Izvestiya, Atmos Ocean Phys, 40, 54-67, 2004.

Russell, P. B., Bergstrom, R. W., Shinozuka, Y., Clarke, A. D., DeCarlo, P. F., Jimenez, J. L., Livingston, J. M., Redemann, J., Dubovik, O., and Strawa, A.: Absorption Angstrom Exponent in AERONET and related data as an indicator of aerosol composition, Atmos. Chem. Phys., 10, 1155-1169, doi:10.5194/acp-101155-2010, 2010.

Sayer, A. M., Hsu, N. C., Bettenhausen, C., Jeong, M.-J., Holben, B. N., and Zhang, J.: Global and regional evaluation of overland spectral aerosol optical depth retrievals from SeaWiFS, Atmos. Meas. Tech., 5, 1761-1778, doi:10.5194/amt-5-1761-2012, 2012.

Schuster, G. L., Dubovik, O., and Holben, B. N.: Ångström exponent and bimodal aerosol size distributions, J. Geophys. Res., 111, D07207, doi:10.1029/2005JD006328, 2006.

Schuster, G. L., Vaughan, M., MacDonnell, D., Su, W., Winker, D., Dubovik, O., Lapyonok, T., and Trepte, C.: Comparison of CALIPSO aerosol optical depth retrievals to AERONET measurements, and a climatology for the lidar ratio of dust, Atmos. Chem. Phys., 12, 7431-7452, doi:10.5194/acp-12-7431-2012, 2012.

Song, C. H., Park, M. E., Lee, K. H., Ahn, H. J., Lee, Y., Kim, J. Y., Han, K. M., Kim, J., Ghim, Y. S., and Kim, Y. J.: An investigation into seasonal and regional aerosol characteristics in East Asia using model-predicted and remotely-sensed aerosol properties, Atmos. Chem. Phys., 8, 6627-6654, doi:10.5194/acp-8-6627-2008, 2008.

Sterk, G. and Goossens, D.: Emissions of soil dust and related problems in Europe: an overview, DustConf International Conference, Maastricht, the Netherlands, 23-24 April 2007, 12 pp., 2007.
Stohl, A., Berg, T., Burkhart, J. F., Fjae'raa, A. M., Forster, C., Herber, A., Hov, Ø., Lunder, C., McMillan, W. W., Oltmans, S., Shiobara, M., Simpson, D., Solberg, S., Stebel, K., Ström, J., Tørseth, K., Treffeisen, R., Virkkunen, K., and Yttri, K. E.: Arctic smoke - record high air pollution levels in the European Arctic due to agricultural fires in Eastern Europe in spring 2006, Atmos. Chem. Phys., 7, 511-534, doi:10.5194/acp-7-511-2007, 2007.

Tanré, D., Bréon, F. M., Deuzé, J. L., Herman, M., Goloub, P., Nadal, F., and Marchand, A.: Global observation of anthropogenic aerosols from satellite, Geophys. Res. Lett., 28, 45554558, 2001.

Tanré, D., Bréon, F. M., Deuzé, J. L., Dubovik, O., Ducos, F., François, P., Goloub, P., Herman, M., Lifermann, A., and Waquet, F.: Remote sensing of aerosols by using polarized, directional and spectral measurements within the A-Train: the PARASOL mission, Atmos. Meas. Tech., 4, 1383-1395, doi:10.5194/amt-4-1383-2011, 2011.

Uscka-Kowalkowska, J.: An analysis of the extinction of direct solar radiation on Mt. Kasprowy Wierch, Poland, Atmos. Res., 134, 175-185, 2013.

Witte, J. C., Douglass, A. R., da Silva, A., Torres, O., Levy, R., and Duncan, B. N.: NASA A-Train and Terra observations of the 2010 Russian wildfires, Atmos. Chem. Phys., 11, 9287-9301, doi:10.5194/acp-11-9287-2011, 2011.

Yoon, J., von Hoyningen-Huene, W., Kokhanovsky, A. A., Vountas, M., and Burrows, J. P.: Trend analysis of aerosol optical thickness and Ångström exponent derived from the global AERONET spectral observations, Atmos. Meas. Tech., 5, 12711299, doi:10.5194/amt-5-1271-2012, 2012.

Zawadzka, O., Markowicz, K. M., Pietruczuk, A., Zielinski, T., and Jaroslawski, J.: Impact of urban pollution emitted in Warsaw on aerosol properties, Atmos. Environ., 69, 15-28, doi:10.1016/j.atmosenv.2012.11.065, 2013.

Zawadzka, O., Makuch, P., Markowicz, K. M., Zieliński T., Petelski, T., Ulevičius, V., Strzałkowska, A., Rozwadowska, A., and Gutowska, D.: Studies of Aerosol Optical Depth with the Use of Microtops II Sun-photometers and MODIS Detectors in Coastal Areas of the Baltic Sea, Acta Geophys., 62, 400-422, doi:10.2478/s11600-013-0182-5, 2014. 